\title{
Premature Fruit Drop in Saw Palmettos Caused by Colletotrichum gloeosporioides
}

\author{
M. E. Carrington, Range Science Department, P. D. Roberts, N. V. R. R. Urs, Plant Pathology Department, \\ Southwest Florida Research and Education Center (SWFREC), University of Florida, 2686 SR 29 N, Immokalee, \\ FL 34142; R. J. McGovern, T. E. Seijo, Plant Pathology Department, Gulf Coast Research and Education Center, \\ University of Florida, 500760 St E, Bradenton, FL, 34203; and J. J. Mullahey, Range Science Department, \\ SWFREC, University of Florida
}

\begin{abstract}
Carrington, M. E., Roberts, P. D., Urs, N. V. R. R., McGovern, R. J., Seijo, T. E., and Mullahey, J. J. 2001. Premature fruit drop in saw palmettos caused by Colletotrichum gloeosporioides. Plant Dis. 85:122-125.

Saw palmetto (Serenoa repens) is a palm species that grows naturally in the southeastern coastal plain of the United States and is most abundant in Florida. Extracts from saw palmetto fruit are sold worldwide in pharmaceutical and dietary supplements in a market valued at $\$ 2$ billion per year. Lesions on blossoms and fruit and premature fruit drop were first observed in 1996. In 1997, premature fruit drop resulted in 100\% loss of fruit in saw palmetto in central and south Florida. In 1998, fruit loss was 8 to 59\%. A fungus was consistently isolated from diseased saw palmetto spadices and fruit and identified as Colletotrichum gloeosporioides based on morphological, immunological, and genetic characteristics. Inoculation of spadices of containerproduced saw palmettos with $C$. gloeosporioides resulted in similar disease symptoms and subsequent reisolation of the causal agent. The cross-infection potential of isolates was demonstrated by infection of other hosts. This is the first report of $C$. gloeosporioides causing disease on saw palmetto.
\end{abstract}

Additional keywords: medicinal plant extracts, Serenoa repens

Saw palmetto fruit are at the center of a growing market for pharmaceutical and dietary supplements. Fruit extracts are used in the treatment of benign prostatic hyperplasia (BPH), a medical condition that affects $40 \%$ of men aged 70 years or older $(5,20)$. The supplement market that includes saw palmetto products has worldwide sales of over $\$ 2$ billion with increases of $15 \%$ annually since 1992 .

Saw palmetto (Serenoa repens (Bart.) Small) is a low-growing, bushy palm that grows naturally in the southeastern coastal plain of the United States. Although the native range extends westward to Louisiana and northward to South Carolina, saw palmettos are most abundant in Florida where they grow in seasonally flooded and

Corresponding author: P. D. Roberts

E-mail: pdr@gnv.ifas.ufl.edu

J. J. Mullahey's current address: West Florida Research and Education Center, Milton, FL 32572.

Florida Agricultural Experiment Station Journal Series R-07486.

Accepted for publication 23 October 2000.

Publication no. D-2000-1121-01R

(c) 2001 The American Phytopathological Society upland habitats $(10,18)$. Flowers and fruit are borne on spadices that emerge from the leaf bases predominately during March and April with each spadix bearing thousands of tiny white flowers. The fruit are oneseeded, ellipsoid or subglobose, and 16 to $25 \mathrm{~mm}$ long and 12 to $19 \mathrm{~mm}$ wide when mature. Immature green fruit are present from May through July, turn orange by August, and ripen to bluish-black in September or October (10).

To meet the world demand for products of saw palmetto fruit, 7 to $18 \times 10^{6} \mathrm{~kg}$ of saw palmetto fruit were harvested in Florida from 1996 to 1998. During 1997, however, the fruit harvest was decimated by premature fruit drop. Lesions on flowers and fruit with black, pitted lesions were observed prior to fruit abscission.

Diseases caused by Colletotrichum spp. are widespread on many hosts in Florida and anthracnose continues to be an emerging problem on some hosts such as leatherleaf fern and bell pepper (15; P. D. Roberts, unpublished data). Colletotrichum isolates may show specificity for a single host or several hosts $(3,4,7,8)$. In Florida, noncultivated and alternate hosts provide inocula for anthracnose diseases of the leatherleaf fern and strawberry $(17,21)$. Although the ability of a Colletotrichum isolate from a specific host to cross-infect other hosts may not have taxonomic utility, understanding its cross-infection potential aids in characterizing the biology of the pathogen and the epidemiology of the disease $(7,8)$.

The objectives of this study were first, to isolate and identify the pathogen(s) associated with the saw palmetto fruit abscission; second, to quantify the premature fruit drop that occurred in 1997 and 1998 and, third, to demonstrate the cross-infection potential of isolates.

\section{MATERIALS AND METHODS}

Isolation and characterization of the pathogen. Spadices had fruit abscission and fruit with black sunken lesions (Fig. 1). Acervuli with setae were observed in lesions. Cylindrical conidia were present in the acervuli. These observations suggested a preliminary diagnosis of Colletotrichum.

A fungus was isolated from symptomatic fruit tissue that was surface sterilized in $0.525 \% \mathrm{NaOCl}$ and plated on either corn meal agar (CMA) or Czapek's agar (Difco, Detroit, MI). Plates were incubated at $27^{\circ} \mathrm{C}$ with a $12 \mathrm{~h}$ photoperiod for 2 to 5 days. Mycelium from margins of developing colonies was transferred to CMA. Singlespore cultures were isolated by suspending conidia produced on CMA in $1 \mathrm{ml}$ of sterile water, dilution plating to CMA, and transferring a single, germinating spore to CMA. Cultures were maintained on slants of potato dextrose agar (PDA) (Difco) at 4 and $-80^{\circ} \mathrm{C}$ in $15 \%$ glycerol. Measurements were made of conidia, appressoria, acervuli, and setae from cultures grown on $4 \times$ $4 \mathrm{~mm}$ pieces of CMA agar by the slide culture technique and incubated at $27^{\circ} \mathrm{C}$ for $72 \mathrm{~h}$ (13).

An enzyme-linked immunosorbent assay (ELISA) specific for $C$. acutatum (Adgen Ltd., Auchincruvie, Scotland, UK) was used to test isolates of Colletotrichum sp. pathogenic to saw palmetto. Samples tested were conidial suspensions made from single-spore cultures. Additional isolates from saw palmetto were further characterized genetically by assays with polymerase chain reaction (PCR). The oligonucleotide primers specific for $C$. acutatum or $C$. gloeosporioides and methodology of Brown et al. were used in PCR 
assays (6). Two isolates of C. gloeosporioides from hosts Ludwigia and Aeschynomene and a $C$. acutatum isolate from host Malus (provided by D. O. TeBeest, University of Arkansas) were used as controls in PCR and ELISA assays. A positive control of $C$. acutatum was provided with the ELISA kit.

Six isolates from saw palmetto were grown at different temperatures. The centers of three plates that contained $20 \mathrm{ml}$ of PDA were inoculated with a $4 \mathrm{~mm}$ plug taken from the edge of a 3-day-old culture also grown on PDA. Plates were sealed with Parafilm and incubated at 12, 18, $19.5,23,26,31$, and $35^{\circ} \mathrm{C}$ in the dark for 7 days. Colony diameters were measured and the area of growth calculated. The experiment was performed twice.

Pathogenicity and cross-infection potential studies. Four saw palmetto plants, 2- to 3-ft high with 5 to 10 fronds and one or more spadices bearing fruit were grown in 100-liter containers and used for inoculation. A conidia suspension was adjusted to $10^{6} \mathrm{ml}^{-1}$ prepared from CMA plates with 7- to 10-day-old cultures flooded with sterile water. The spadices were sprayed to run-off with the spore suspension using a compressed air canister. Four control plants were inoculated with sterile water. Each spadix was covered with a plastic bag for $48 \mathrm{~h}$ to maintain high humidity. The plants were placed in growth chambers (Conviron, Winnipeg, Canada) with a 12-h photoperiod, and day and night temperatures of 27 and $23^{\circ} \mathrm{C}$, respectively. Plants were watered daily and monitored for symptoms for 60 days. Colletotrichum sp. was reisolated from lesions as described.

Experimental hosts for cross-infection assays were selected based on their prevalence in commercial production in southwest Florida. Seedlings and detached fruit of watermelon (Citrullus lanatus), summer squash (Cucurbita pepo), cantaloupe (Cucumis melo), bell pepper (Capsicum annuum), and tomato (Lycopersicon esculentum) were inoculated. Detached fruit of eggplant (Solanum melongena) and snapbean (Phaseolus vulgaris) also were inoculated. Inoculations of blossoms and fruit were performed on citrus variety Hamlin. For all plants except citrus, inoculation and incubation of plants and fruit were as described. Citrus blossoms were assayed using the detached blossom method of Agostini et al. (2). Symptoms were recorded at 7 to 14 days after inoculation (DAI) and the fungus was recovered from symptomatic tissue.

Disease incidence and fruit loss in 1997 and 1998. Disease incidence was measured as a percentage of saw palmettos with fruit loss that was assessed by marking 125 saw palmettos at each site in Collier, Sarasota, Highlands, and Polk counties, FL. The counties are located in southwest, west central, central, and south central Florida, respectively. Saw palmet- tos were located on 20 random, 5-m-line transects at each site and the number of plants that produced flowers and fruit were recorded each month. From January to April in 1997 and 1998, flowering spadices were marked as they emerged. From May to August, incidence of fruit loss was recorded as a percent decrease in saw palmettos producing fruit. The decrease in saw palmettos producing fruit was calculated as the relative percent decrease $=$ $\left[\left(F_{t-1}-F_{t}\right) / F_{t-1} \times 100 \%\right] \times\left[F_{t-1} / F_{0}\right]$, where $F_{t}$ $=$ number of fruiting saw palmettos in the present month, $F_{t-1}=$ number of fruiting saw palmettos in the previous month, and $F_{0}=$ total number of fruiting saw palmettos for the year.

Confirmation of fruit loss due to infection by Colletotrichum and progress of fruit loss on a saw palmetto plant was assessed at three separate sites within Collier County by marking 10 to 11 saw palmettos with green fruit exhibiting lesions caused by Colletotrichum sp. Saw palmetto fruit was counted three times at 2-to-5-week intervals from July through October 1997. Fruit abscission from saw palmetto at each count was ascribed to Colletotrichum if symptoms of infection were present on fruit at prior assessment. Symptoms of infection by Colletotrichum included depressed, brown to black lesions, often with a gray, sporulating center; black, shriveled fruit; and premature fruit dehiscence from spadices. Microscopic examination of at least three fruit per site confirmed the presence of Colletotrichum sp. Damage by the caterpillar Atheloca sp. was identified by its presence or signs of infestation (9). Percent fruit loss during each period between counts was calculated for each saw palmetto. Mean and standard deviation of percent fruit loss per saw palmetto count- ing period were calculated for each of the three sites. Data were not collected in 1998 due to low disease incidence.

Rainfall data for 1997 and 1998 were obtained from weather stations at the Southwest Florida Research and Education Center (SWFREC Weather Station Data Archives, 1999), Myakka River State Park, Avon Park Air Force Range, and Archbold Biological Station in Collier, Sarasota, Polk, and Highlands counties, respectively. Weather stations were located on experimental sites. High and low temperatures for 1997 and 1998 were obtained for the Collier County site only.

\section{RESULTS}

Isolation and characterization of the pathogen. Colonies of the pathogen on PDA were dense and produced whitegrayish aerial mycelium and dark brown to black conidial masses. Acervuli were brown, 60 to $180 \mu \mathrm{m}$ in length $\times 40$ to 100 $\mu \mathrm{m}$ wide with black setae that were 1 to 4 septate and 70 to $190 \mu \mathrm{m}$ in length. Conidia were 7.5 to $17.5 \times 2.5$ to $3.75 \mu \mathrm{m}$ hyaline, straight, and rounded at both ends. Appressoria were 5 to $15 \times 5$ to $9 \mu \mathrm{m}$, clavate or irregular. The isolate was identified as $C$. gloeosporioides (16). Isolates from saw palmetto tested negative for $C$. acutatum by ELISA and PCR, but positive for $C$. gloeosporioides by PCR. Five of the six isolates produced optimum growth as measured by colony area at $26^{\circ} \mathrm{C}$ (Fig. 2). Average growth for isolates was reduced by $80 \%$ at $12^{\circ} \mathrm{C}$ and by $30 \%$ at $31^{\circ} \mathrm{C}$ or higher compared with growth at $26^{\circ} \mathrm{C}$.

Pathogenicity and cross-infection potential studies. Small black lesions occurred on artificially inoculated saw palmetto fruit at 21 DAI and fruit was entirely black after 35 days. Grayish black

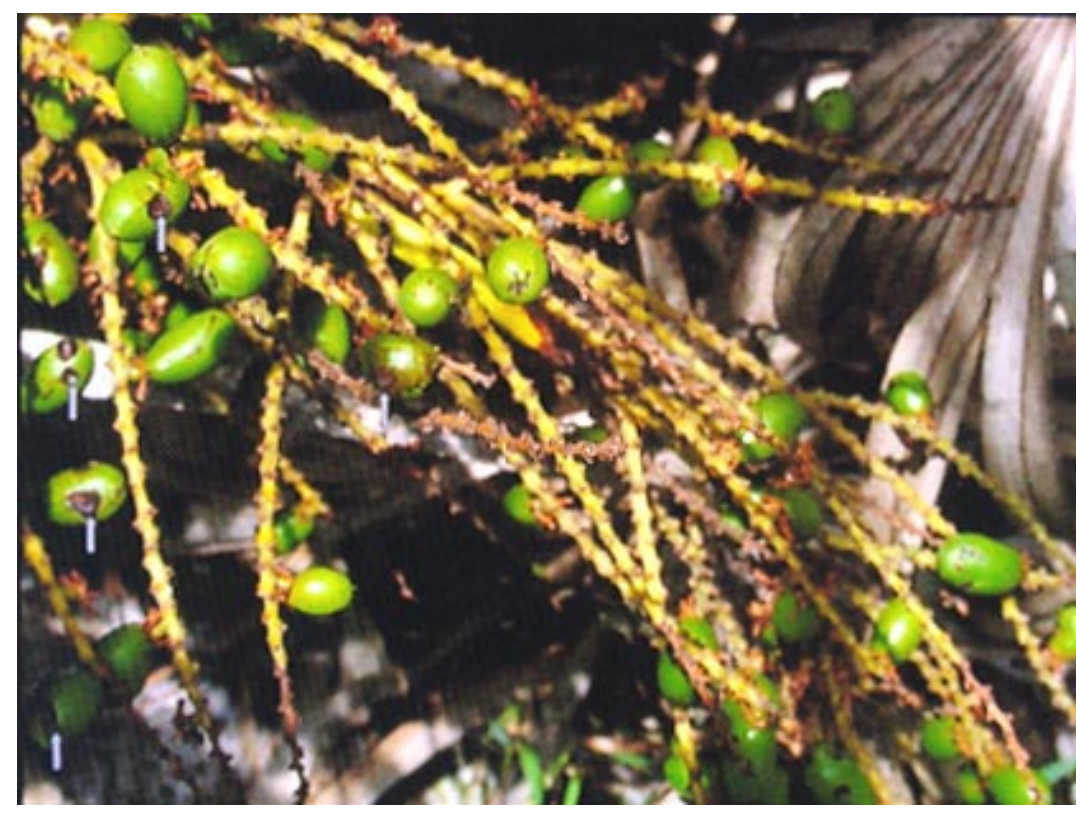

Fig. 1. Saw palmetto spadices exhibiting fruit abcission. Lesions on fruit caused by Colletotrichum gloeosporioides are marked with an arrow. 
mycelium was observed at $10 \times$ magnification. Mycelium and acervuli were present in lesions and fruit dropped from spadices. A morphologically identical fungus was reisolated to fulfill Koch's postulates from symptomatic fruit. Control plants were asymptomatic.

Tomato and eggplant fruit developed watersoaked, sunken lesions $72 \mathrm{~h}$ after inoculation. Reddish-brown lesions occurred on citrus petals at $48 \mathrm{~h}$. Acervuli and mycelium were present in lesions and a fungus identical to the inoculated strain was recovered. Neither symptoms nor growth of mycelium were observed on the seedlings and fruit of watermelon, summer squash, cantaloupe, snapbean, and bell pepper at 14 DAI. Seedlings of tomato and citrus fruit were asymptomatic.

Disease incidence and fruit loss in 1997 and 1998. Disease progress recorded as the percentage of the 125 saw palmettos that flowered and then exhibited total fruit loss at each site per sample date in 1997 and 1998 is shown in Figure 3A and B. The percentage of saw palmettos with fruit loss increased monthly from May to August both years except at two sites in 1998. The percentage of plants with total fruit loss ranged from 56 to $100 \%$ in August 1997 (Fig. 3A). The percentage of saw palmettos with total fruit loss was reduced in 1998 compared to 1997 and ranged from 59 to 4\% in August (Fig 3B).

In 1997, fruit loss reached $100 \%$ on 30 of the 31 saw palmettos with fruit that had exhibited symptoms of infection in July. The majority of the fruit decrease $(90 \%)$ was correlated to infection by Colletotrichum sp. The remaining $10 \%$ of the losses were attributed to damage by insects that were predominately Atheloca sp. (data not shown).

Rainfall was greater during the period of flowering and fruit set in April and May 1997 compared with the previous 10-yr average and in 1998. Rainfall in April
$1997(16 \mathrm{~cm})$ was twice the 1989 to 1996 average $(8 \mathrm{~cm})$ and May 1997 rainfall (13 $\mathrm{cm})$ was 1.6 times the 10 -year average $(8$ $\mathrm{cm})$ at the site in Collier County. Rainfall in April 1997 (20 cm) was greater compared to April 1998 (3 cm) in Sarasota County. Rainfall in May was relatively the same (within $2 \mathrm{~cm}$ ) in 1997 and 1998 in Polk and Highlands counties but was much higher in $1997(14 \mathrm{~cm})$ compared to 1998 $(2 \mathrm{~cm})$ in Sarasota County. Rainfall in January, February, and March at all four sites was on average two times higher in 1998 than 1997.

The average high temperatures recorded in Collier County in 1997 and 1998 ranged from 28 to $34^{\circ} \mathrm{C}$ and the average low temperatures ranged from 22 to $15^{\circ} \mathrm{C}$. In general, the average temperature between the years varied by only 2 to $7^{\circ} \mathrm{C}$.

\section{DISCUSSION}

Premature fruit drop in saw palmetto caused by Colletotrichum gloeosporioides is believed to be the first reported in the family Arecaceae in the Western Hemisphere. A similar disease of inflorescence of the betel nut (Areca catechu) that resulted in severe fruit losses due to abscission and nut rot was attributed to $C$. gloeosporioides in India (14). Isolates from saw palmetto were characterized as $C$. gloeosporioides by colony color, size, and shape of conidia, optimal temperature, growth rate, presence of setae, and appressoria (16). Positive results with PCR using oligonucleotide primers specific for $C$. gloeosporioides confirmed its identity $(6,12)$

A single host may be infected by several Colletotrichum spp. or a single species of Colletotrichum may infect more than one host $(3,4,8,11)$. Cross-infection of noncultivated and alternate hosts occurs for Colletotrichum isolates from leatherleaf fern and strawberry in Florida $(17,21)$. Characterization of the isolates from saw palmetto

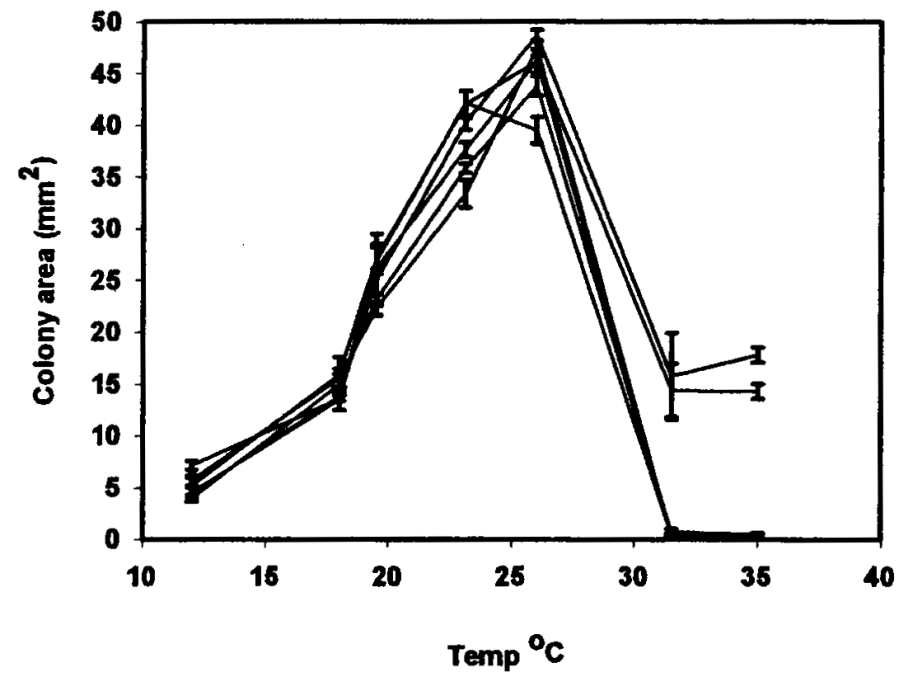

Fig. 2. Growth of isolates of Colletotrichum gloeosporioides from saw palmetto measured as colony area $(\mathrm{cm} 2)$ on corn meal agar (Difco) at six temperatures for 7 days.

by artificial inoculation demonstrated that these isolates are capable of infecting multiple hosts. The ability to cross-infect other hosts may have implication on the epidemiology of this disease such as providing inocula for other hosts or vice-versa. Freeman et al. (7) reported that isolates of C. gloeosporioides and C. acutatum from several hosts infected detached fruits of other hosts. They concluded, however, that these experiments were conducted under extreme conditions and that naturally infected fruit provided no evidence that cross-infection had occurred under field conditions. The ability of these isolates to cause symptoms on hosts other than saw palmetto demonstrates their potential for cross-infection but additional investigation is needed to determine if cross-infections occurs naturally and whether saw palmetto provides a reservoir for Colletotrichum pathogenic to other crops.

The widespread distribution of the epidemic in south and central Florida indicates that this was probably not a new disease but was previously undocumented because of the lack of demand for saw palmetto fruit. This is supported by an observation of fruit loss of saw palmetto due to an unidentified cause in 1996 ( $R$. McGovern, unpublished data). The contributing factor for the near $100 \%$ fruit loss epidemic was probably the above average amount of rainfall during flowering and fruit set in April and May 1997. The greater amount of rainfall in January
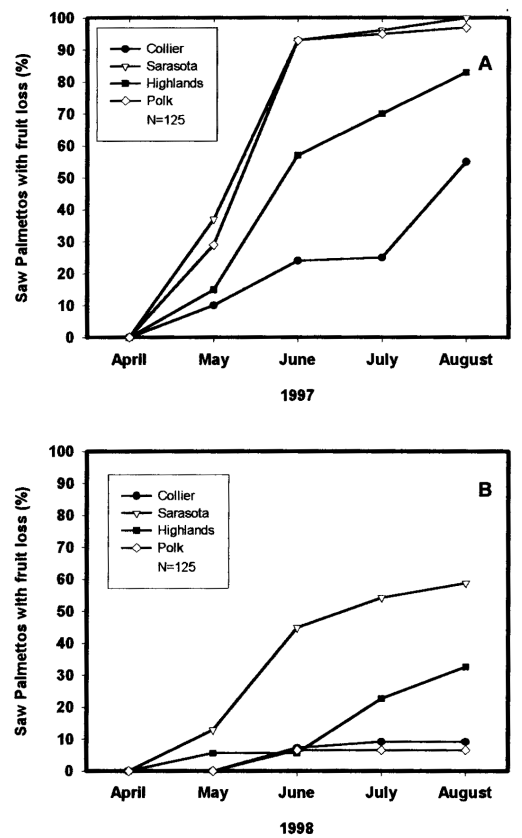

Fig. 3. Percent saw palmettos with fruit loss. A, 1997; B, 1998. A total of 500 saw palmettos were monitored in four sites in southwest (Collier Co.), west central (Sarasota Co.), south central (Highlands Co.), and central (Polk Co.) Florida. 
through March 1998 did not result in significant losses of saw palmetto fruit. Thus, similar to postbloom fruit drop (C. acutatum) on citrus, the time and amount of rainfall during flowering appears to be critical for disease development $(1,19)$. The determination that isolates grew optimally at $26^{\circ} \mathrm{C}$ was useful for determining the conditions for artificial inoculation of saw palmetto but temperature in both years was relatively stable and did not appear to influence disease development.

Control methods, such as spraying with fungicides, will probably not be practical for the wild saw palmetto because of the asynchronous flowering and the application of fungicides to natural, expansive range land that contains many different plant species would not be economical. Currently, land with saw palmettos is managed primarily by burning. If more is understood about the pathogen's life-cycle, however, it may be possible to manipulate burn times to reduce the inoculum potential and trigger uniform flowering. For example, a spring burn prior to April might reduce the reservoir of inoculum on saw palmettos just prior to flowering.

\section{LITERATURE CITED}

1. Agostini, J. P., and Timmer, L. W. 1992. Selective isolation procedures for differentiation of two strains of Colletotrichum gloeosporioides from citrus. Plant Dis. 76:1176-1178.

2. Agostini, J. P., Timmer, L. W., and Mitchell, D. J. 1992. Morphological and pathological characteristics of strains of Colletotrichum gloeosporioides, the cause of citrus postbloom fruit drop. Phytopathology 82:13771382.

3. Alahakoon, P. W., Brown, A. E., and Sreenivasaprasad, S. 1994. Cross-infection potential of genetic groups of Colletotrichum gloeosporioides on tropical fruits. Physiol. Mol. Plant Pathol. 44:93-103.

4. Bernstein, B., Zehr, E. I., Dean, R. A., and Shabi, E. 1995. Characteristics of Colletotrichum from peach, apple, pecan, and other hosts. Plant Dis. 79:478-482.

5. Berry, S. L, Coffey, D. S., Walsh, P. C., and Ewing, L. L. 1984. The development of human benign prostatic hyperplasia with age. J. Urol. 132:474-479.

6. Brown, A. E., Sreenivasaprasad, S., and Timmer, L. W. 1996. Molecular characterization of slow-growing orange and key lime anthracnose strains of Colletotrichum from citrus as C. acutatum. Phytopathology 86:523527.

7. Freeman, S., Katan, T., and Shabi, E. 1998. Characterization of Colletotrichum species responsible for anthracnose diseases of various fruits. Plant Dis. 82:596-605.

8. Freeman, S., and Shabi, E. 1996. Crossinfection of subtropical and temperate fruits by Colletotrichum species from various hosts. Physiol. Mol. Plant Path. 49:395-404.

9. Habeck, D. H., and Nickerson, J. C. 1982. Atheloca subrufella (Hulst), a pest of coconuts. Circular No. 241, Div. Plant Ind. Entomol, Gainesville, FL.

10. Hilmon, J. B. 1968. Autoecology of sawpalmetto (Serenoa repens (Bartr.) Small). Ph.D. diss., Duke University, Raleigh, NC.

11. Legard, D. E. 1999. Colletotrichum diseases of strawberry. Proceedings of the ICM6 Colletotrichum Workshop, Tel Aviv, Israel, 8/98. D. Prosky, S. Freeman, and M. Dickman, eds. American Phytopathological Society. In press.

12. Mills, P. R., Sreenivasaprasad, S., and Brown, A. E. 1992. Detection and differentiation of Colletotrichum gloeosporioides isolates using PCR. FEMS Microbiol. Let. 98:137-144.

13. Riddel, R. W. 1950. Permanent stained mycological preparations obtained by slide culture. Mycologia 42:265-270.

14. Saraswathy, N., Kott Reddy, M., and Radhakrishnan Nair, R. 1977. Colletotrichum gloeosporioides causing inflorescence dieback, button shedding, and nut rot of betel nut palm. Plant Dis. Reporter 61:1721-174.

15. Stamps, R. H., Strandberg, J. O., and Norman, D. J. 1998. Incidence, severity, and control of anthracnose in leatherleaf fern in Florida. Proc. Fla. State Hort. Soc. 110:115-118.

16. Sutton, B. C. 1992. The genus Glomerella and its anamorph Colletotrichum. Pages 1-26 in: Colletotrichum: Biology, Pathology, and Control. J. A. Bailey and J. J Jeger, eds. CAB Int. Wallingford, UK.

17. Strandberg, J. O. 1999. Pathogenicity of the fern anthracnose fungus, Colletotrichum acutatum, on wild and cultivated ferns in Florida. Proc. Fla. State Hort. Soc. 112:274 277.

18. Tanner, G., Mullahey, J. J., and Maehr, D. 1996. Saw-palmetto: An ecologically and economically important native palm. IFAS Circ. WEC-109, Gainesville, FL.

19. Timmer, L. W., and Zitko, S. E. 1993. Relationship of environmental factors and inoculum levels to the incidence of postbloom fruit drop of citrus. Plant Dis. 77:501-504.

20. Wilt, T., Ishani, A., and Mulrow, C. 1998 Saw palmetto extracts for treatment of benign prostatic hyperplasia: A systematic review. J. Am. Med. Assoc. 280:1604-1609.

21. Xiao, C. L., and Legard, D. E. 2000. Pathogenicity of Colletotrichum gloeosporioides isolates from noncultivated hosts on crown of strawberry. Phytopathology 90:S86. 